\title{
日本鉱物科学会研究奨励賞第11回受賞者 受賞記念研究紹介
}

\section{衝撃を経験した隕石に含まれる高圧相}

\author{
High-pressure polymorphs in shocked meteorites
}

宮原 正明(Masaaki MIYAHARA)*,**

\begin{abstract}
Some meteorites experienced transient high-pressure and -temperature conditions on its parent-body. High-pressure polymorphs form in and around shock-melt veins of shocked meteorites. Recent developed Nano-technologies such as TEM and FIB system allow us to scrutinize high-pressure polymorphs in shocked meteorites. We here introduce the occurrences, natures and formation mechanisms of high-pressure polymorph of olivine and silica in shocked meteorites and their implications for planetary science.
\end{abstract}

Keywords: Shocked meteorite, High-pressure polymorph, Olivine, Silica

\section{I. はじめに}

天体の衝突現象は天体の成長 ·進化の基本要素の 1 つで ある。例えば, 小惑星「イトカワ」も母天体の小惑星が衝 突により砕け, 破片の一部が再集積し現在の形となった事 (Nakamura et al., 2011), 回収試料の形状は衝突の影響を 受けている事が示唆されている(Nakamura et al., 2012)。 隕石に記録された天体の衝突現象の記録は 1）角碟化，2) 鉱物粒子の扁平化，3）鉱物への歪久. 欠陥の導入，4）長 石のマスケリナイト化，5）衝撃熔融脈，6）高圧相などが ある。天体同士が衝突した際, 衝撃波の伝播で引き起こさ れる高圧に加え, 岩石中の割れ目に沿った摩擦や応力の集 中で岩石の一部が局所的に高温条件下におかれ溶融する。 岩石中のそのような部分は黒色の脈状を呈すことが多く “衝撃溶融脈”と呼ばれる (Fig. 1)。衝撃溶融脈の内部々 その周囲ではケイ酸塩, リン酸塩鉱物, シリカなどの高密 度の多形(高圧相)が生成している。高圧相は地球深部を構 成する物質であり, 古くからマルチアンビル, ダイヤモン ドアンビルセルといった高圧発生装置を用いた高温・高圧 合成実験により, その結晶構造変化, 密度, 弾性波速度, 化学組成や相平衡等の研究が精力的に行われている。高圧 相の多くは地下数百キロ〜数千キロにも及ぶ地球マントル 深部に存在すると考えられているが, これらの地球深部物 質を直接手に入れることは困難である。宇宙空間では巨大

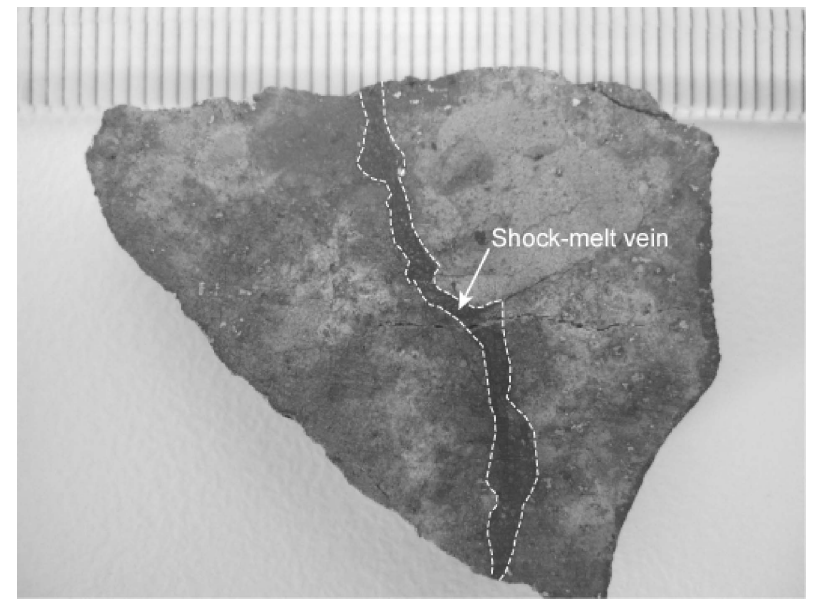

Fig. 1. Photograph of a shocked meteorite (Dar al Gani 477 L6 ordinary chondrite) with a shock-melt vein.

な質量を持つ天体同士が高速で衝突し，非常に短時間では あるが地球深部に相当する高温・高圧状態が達成され高圧 相が生じる。隕石中の高圧相の研究はもともと地球深部物 質のアナログ物質としての側面が大きかった。しかし, 最 近ではそうした視点からだけでなく，過去に起きた天体衝 突の規模(衝突速度や母天体のサイズ等), 衝突年代, 衝突 後の母天体からの放出メカニズムを解明することを目的と した研究が増えつつある。隕石中の高圧相は衝撃溶融内部

doi: $10.2465 /$ gkk. 131120

(平成 25 年 11 月 20 日受付, 平成 25 年 11 月 29 日受理, 担当編集委員: 赤坂正秀)

* 東北大学大学院理学研究科地学専攻, 干980-8578 宮城県仙台市青葉区荒巻字青葉 6-3

** 現所属 : 広島大学理学研究科地球惑星システム学専攻, 干739-8526 広島県東広島市鏡山 1-3-1

* Institute of Mineralogy, Petrology and Economic geology, Graduate School of Science, Tohoku University, 6-3 Aramaki Aza Aoba, Aoba-ku, Sendai 980-8578, Japan

** Present address: Department of Earth and Planetary Systems Science, Graduate School of Science, Hiroshima University, 1-3-1 Kagamiyama, Higashi-Hiroshima 739-8526, JapanＥ-mail: miyahara@hiroshima-u.ac.jp 
とその周囲に偏在している。また，その多くがサブミクロ ンサイズであったため，以前はその観察・分析は困難を極 めた。しかし, 近年は急速に発達した透過型電子顕微鏡 (TEM) を中心とする局所分析技術(電子線回折，元素分 析, 集束イオンビーム加工装置, 放射光 X 線回折等)によ り隕石中の高圧相の研究が容易となり, 地球惑星深部物質 や天体衝突のプロセスを理解する為の様々な情報を引き出 すことが出来るようになってきた。本稿では近年著者らが 取り組んだ研究を中心として, 衝撃を経験した隕石に含ま れるオリビンとシリカ高圧相の概要とそこから読反取れる 隕石母天体の衝突プロセスや惑星進化史について紹介する。

\section{II. 隕石中のオリビン高圧相}

オリビンは地球の地殼と上部マントルを構成する主要な 鉱物の 1 つである。高温・高圧合成実験装置を用いた研究 結果から，オリビンは地球の遷移帯(地表面下：410～660 $\mathrm{km})$ に相当する温度・圧力条件下で逆スピネル構造を持つ ワズレアイト，スピネル構造を持つリングウッダイトに相 転移することが予想されている(例えば，Presnall, 1995)。 オリビンは隕石を構成する主要な鉱物の1つでもある。天 然のワズレアイトとリングウッダイトは衝撃を経験した隕 石からのみ発見されている。これまでの研究で H6，L6， LL6 タイプの普通コンドライト, 月起源隕石, 火星起源 隕石中の衝撃溶融脈(或はメルトポケット)の内部とその周 囲にワズレアイト，リングウッダイト或はその両方に置換 されたオリビンが見出されている(Binns et al., 1969; Price et al., 1983; Chen et al., 1996; Kimura et al., 2000; Ohtani et al. 2004; Chen et al., 2004, 2006, 2007; Badjukov et al., 2005; Barrat et al., 2005; Miyahara et al., 2008, 2009, 2010; Fritz and Greshake, 2009; Ozawa et al., 2009; Xie et al., 2010; Zhang et al., 2010; Feng et al., 2011; Greshake et al., 2013; Baziotis et al., 2013; Acosta-Maeda et al., 2013; Walton, 2013)。

オリビンからワズレアイト或はリングウッダイトへの相 転移メカニズムは古くから高温・高圧発生装置で合成され た試料を TEM で詳細に観察し，その結果に基づき論じら れてきた(例えば，Kerschhofer et al., 1996, 2000)。一方， 天然試料(隕石)中でのオリビンからその高圧相への相転移 メカニズムはほとんど理解されていなかった。ワズレアイ トとリングウッダイトが初めて隕石から発見されたのは 60 80 年代であるが (Binns et al., 1969; Price et al., 1983), その生成メカニズムを解明する手掛かりが得られるように なったのは最近のことである。Ohtani et al. (2004) と Chen et al. (2004) はほぼ同時期にオリビンからリングウッ ダイトへの相転移組織であるリングウッダイトラメラを L6 普通コンドライトの衝撃溶融脈周辺のオリビン粒子か ら見出し (Fig. 2)，この相転移組織を用いたリングウッダ イト生成メカニズムの解明が始まった。このリングウッダ イトラメラを, 当時地球科学分野に導入が進みつつあった

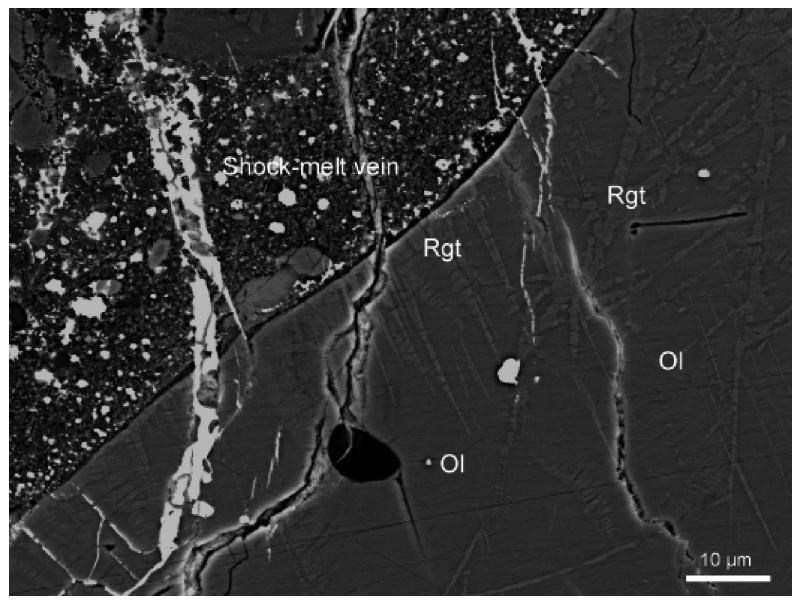

Fig. 2. BSE image of olivine $(\mathrm{Ol})$ grain adjacent to a shock-melt vein in Yamato 791384 ordinary chondrite (L6). Many thin ringwoodite (Rgt) lamellae exist in the olivine grain.

集束イオンビーム (FIB) 加工装置で TEM 用薄膜に加工し， TEM による高分解能像観察や電子線回折を用いた相転移 メカニズムの解明が進んだ(Chen et al., 2007; Miyahara et $a l ., 2010)$ 。高温・高圧合成実験の回収試料の TEM 観察結 果によれば，オリビンからリングウッダイトへの相転移メ カニズムは大きく二つに分けられることが知られていた （例えば, Kerschhofer et al., 1996, 2000)。一つはインコ ヒーレント粒界核生成一界面コントロール成長メカニズム で，オリビンの粒界や三重点に核が形成され，それがリン グウッダイトに成長する。この場合は，オリビンと粒状の リングウッダイトの間には特定の結晶方位関係はない(イ ンコヒーレントな相転移)。もう一つのメカニズムは結晶 内形成メカニズムで，オリビンの(100)面に沿う格子面す べりを起因として積層欠陥が形成され，この(100)積層欠 陥上に薄い板状のリングウッダイトが成長する (Kerschhofer et al., 1998)。この場合オリビンと板状のリ ングウッダイトとの間には特定の結晶方位関係； $(100)_{\mathrm{Ol}} / /$ $\{111\}_{\mathrm{Rw}}$ が認められる(コヒーレントな相転移)。TEM 観 察の結果, 隕石中のリングウッダイトではインコヒーレン ト及びコヒーレント相転移それぞれに相当する証拠が確認 されたが，インコヒーレント相転移メカニズムが支配的で あった (Miyahara et al., 2010)。これは隕石中のオリビン は割れ目や欠陥が多い為, リングウッダイトの核形成に適 する場所が多く, インコヒーレントな相転移が容易に起こ り易いためと考えられる。

オリビンからワズレアイトへの相転移組織は Ozawa et $a l$. (2009)が L6 普通コンドライトの衝撃溶融脈の中から初 めて見出した。ワズレアイト粒子はオリビンの粒界や割れ 目に沿って成長し, 両者の間には化学組成差がなく, 結晶 方位も互いに特別な関係を示さなかった。これはオリビン の粒界等に核が生成し，ワズレアイト粒子が成長したこと を示唆して抢り，インコヒーレント粒界核生成－界面コン 
トロール成長メカニズムで説明が可能である。

オリビンは組成や温度にも依存するが，23-25 GPa を超 える圧力条件下に沶かれる $(\mathrm{Mg}, \mathrm{Fe}) \mathrm{SiO}_{3}$-ペロブスカイ トとマグネシオブスタイト $[(\mathrm{Mg}, \mathrm{Fe}) \mathrm{O}] （+$ スティショ バイト)に分解する。オリビンの分解反応は上部と下部マ ントルを分ける物質境界を作り出すと予想されており重要 な反応の 1 つである。故に多くの研究者が天然試料中に才 リビンの高圧分解反応の証拠を探したが発見には至ってい なかった。一方，オリビンは火星を構成する主要な鉱物の 1 つでもある。火星起源隕石は火星表層上で或は火星から 放出される際にオリビンの安定な圧力領域を大幅に超える 25-80 GPa 相当の衝撃圧縮が記録されているとの見積もり がある(例えば, Stöffler et al., 1986)。そこで Miyahara et al. (2011) は衝撃溶融脈に接するオリビンを FIBで切り出 し TEM を用いて詳細に調べたところ，オリビンが $(\mathrm{Mg}$, $\mathrm{Fe}$ ) $\mathrm{SiO}_{3}$-ペロブスカイト（脱圧時の残留熱によりほぼ非晶 質化）とマグネシオブスタイトに分解した証拠を発見した (Fig. 3)。衝撃溶融脈に接するオリビンではオリビンが 1) 等粒状 $(\mathrm{Mg}, \mathrm{Fe}) \mathrm{SiO}_{3}$-ペロブスカイト+マグネシオブスタ イト，2) ラメラ状 $(\mathrm{Mg}, \mathrm{Fe}) \mathrm{SiO}_{3}$-ペロブスカイト+マグネ シオブスタイトに分解していた。分解組織の違いはオリビ ン結晶内の温度勾配に対応している。すなわち, 等粒状組 織は高温側, ラメラ状組織は低温側で卓越し, この傾向は 高温・高圧合成実験で得られた試料の組織観察結果とも一 致する(e.g., Kubo et al., 2002; Sakai et al., 2009)。これは 温度が低い場合原子の拡散速度が遅くラメラ状組織となる のに対し, 温度が高い場合拡散速度が速く等粒状となる為 と考えられる。

隕石中のオリビン高压相の研究が進むにつれて, 高温 高圧合成実験では観察されたことのない相転移様式が見出

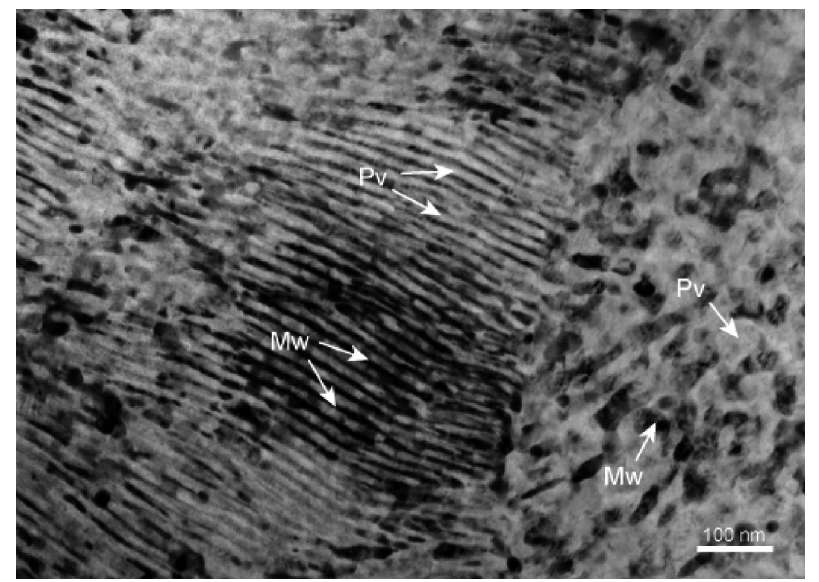

Fig. 3. Bright-field TEM image of decomposed olivine grain adjacent to a shock-melt vein in Martian meteorite, Dar al Gani 735. Two different decomposition textures are recognized; i.e., Left potion consists of lamellar $(\mathrm{Mg}, \mathrm{Fe}) \mathrm{SiO}_{3}$-perovskite $(\mathrm{Pv})$ and magnesiowüstite $(\mathrm{Mw})$. Right portion consists of granular $\mathrm{Pv}$ and $\mathrm{Mw}$.
されるようになってくる。Miyahara et al. (2008, 2009)は L6 普通コンドライトの衝撃溶融脈内部に存在するオリビ ン中からファヤライト成分で最大 $32 \mathrm{~mol} \%$ も組成差を 示す等粒状のワズレアイトとリングウッダイトの集合体を FIB と TEM を用いた観察によって見出した。オリビンが ワズレアイト+リングウッダイトに固相-固相状態で相転 移する場合，ワズレアイトとリングウッダイトの間では鉄 とマグネシウムの相互拡散が起きるが，その拡散速度は非 常に遅く，これほど大きな組成差を衝撃圧縮で引き起こす には非現実的な規模の衝突を考えなければならない(例え ば，数千 $\mathrm{km}$ を超える巨大な隕石母天体の衝突）。Miyahara et al. (2008) はこのワズレアイトとリングウッダイト の集合体は衝撃圧縮で生じた高温・高圧状態でオリビンが 融解し, 高圧状態のままで温度が低下することにより，ま ずマグネシウムに富むワズレアイトが晶出し, さらに温度 が低下して鉄に富むリングウッダイトが生成したと説明し ている。

ワズレアイトやリングウッダイトを含めた高圧相の核形 成と粒成長はカイネティクスに依存している。ランキン・ ユゴニオの式から，物体同士が衝突した際の高圧の持続時 間は物体の大きさに依存する。高圧相の粒子サイズを TEM 等で測定し, 任意のサイズの高圧相が成長するのに 必要な高圧 (及び高温)の持続時間を計算し, 衝突天体のサ イズを見積もる試みも始まっている(Ohtani et al., 2004; Chen et al., 2007; Xie et al., 2006; Xie and Sharp, 2007; Miyahara et al., 2010; Baziotis et al., 2013)。例えば，L6 普 通コンドライトに含まれるリングウッダイトの粒径から, 衝突天体のサイズは $10 \mathrm{~km}$ 以上であったと見積もってい る(Ohtani et al., 2004; Miyahara et al., 2010)。

\section{III. 隕石中のシリカ高圧相}

これまでに天然で発見されたシリカ高圧相としてはコー サイト，スティショバイト， $\alpha-\mathrm{PbO}_{2}$ 型構造を持つザィ フェルタイトがある(Chao et al., 1960, 1962; Sharp et al., 1999; El Goresy et al., 2008)。コーサイトとスティショバ イトは地球上でも見出される数少ない高圧相で, クレー ター周囲の岩石中やキンバーライトの捕獲岩 (Chao et al., 1960, 1962; Smyth and Hatton, 1977; Stähle et al., 2008; Chen et al., 2010)などから発見されている。El Goresy et al. (2000) は火星起源隕石中からバデリアイト $\left(\mathrm{ZrO}_{2}\right)$ に似 た結晶構造を持つシリカ高圧相の存在を指摘しているが, その結晶学的なデータが不十分で新たなシリカ高圧相とし ては認められていない。ダイヤモンドアンビルセルを用い た高温・高圧合成実験では $\mathrm{CaCl}_{2}$ 型と黄鉄鉱型構造をも つシリカ高圧相が合成されているが (Tuchida and Yagi, 1989; Kuwayama et al., 2005), 天然試料からの発見の報告 はまだない。シリカ高圧相の生成メカニズムや安定圧領域 等には未だに未解明な点が多い(例えば, Lakshtanov et $a l ., 2007)$ 。シリカ高圧相は下部マントル最下部に存在す 


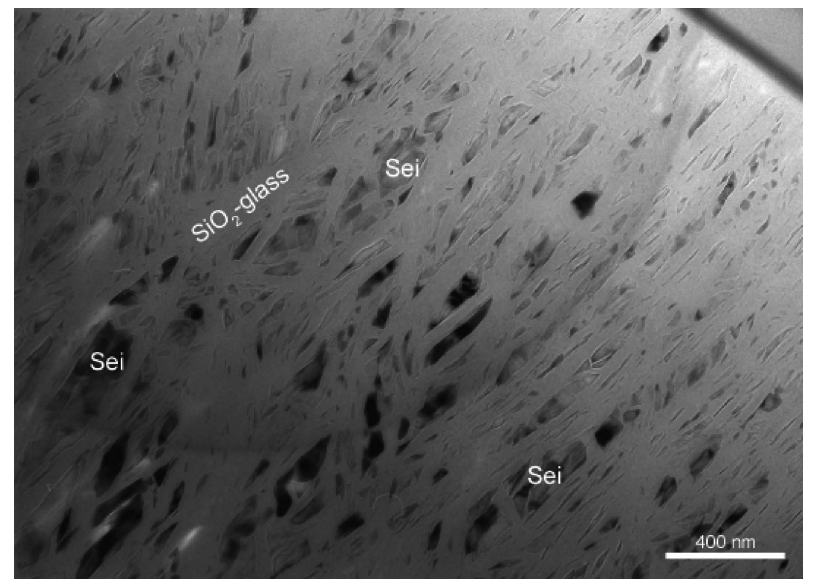

Fig. 4. Bright-field TEM image of seifertite (Sei) in silica grain of lunar meteorite, Northwest Africa 4734. Amorphous or poorlycrystallized silica $\left(\mathrm{SiO}_{2}\right.$-glass $)$ exists between seifertite grains.

ると予測されており，隕石中のシリカ高圧相の研究は地球 深部物質を理解する新たな手掛かりともなり得る。

シリカは隕石を構成する鉱物の割合としては決して大き くはないが, 火星起源隕石, 月起源隕石, 炭素質コンドラ イトからシリカ高圧相が発見されている(Sharp et al., 1999; Barrat et al., 2002; El Goresy et al., 2000, 2013; Weisberg and Kimura, 2010; Ohtani et al., 2011; Bläß, 2013; Miyahara et al., 2013a)。特に近年, 著者らはこれまでほ とんど報告がなかった月起源隕石から次々とシリカ高圧相 を発見した。月には無数のクレーターがあり，月の表層は レゴリスと呼ばれる破砕された岩石からなる層が厚く堆積 している。無数のクレーターと厚いレゴリス層の存在は月 でかつて激しい天体衝突が起きていたことを示唆してい る。しかし，月には激しい天体衝突の痕跡があるにも関わ らずこれまでほとんど高圧相は発見されていなかった。著 者らは月起源隕石に含まれるシリカを FIB, TEM や強力 な放射光によるX 線回折法で調べることによってコーサ イト，スティショバイト，ザイフェルタイト（Fig. 4)を次 々と発見した(Ohtani et al., 2011; Miyahara et al., 2013a)。 また, 月起源隕石の $\mathrm{K}(\mathrm{Ar})-\mathrm{Ar}$ 放射年代に基づき，これ らのシリカ高圧相が後期隕石重爆撃期 (38 41 億年前) とそ れに引き続く天体衝突で生成したことも明らかにした。

\section{IV.おわりに}

天体衝突が地球・惑星進化にとって重要な要素だと認識 され始めたのは比較的最近のことであり，隕石に記録され た衝撃変成に着目した研究が盛んになりつつある(例えば,

Beck et al., 2005; Tschauner et al., 2009; Baziotis et al., 2013; Miyahara et al., 2013a)。物質科学的証拠に基づいて 天体衝突現象を読み解いていく試みは始まったばかりであ る。衝突現象の定量化の試反には多くの不確定要素が含ま れ, 様々な仮定をおいての議論が中心で, “天体衝突現象”
の真の姿が描けるのはまだまだ先のことである。それでも 例えば，月への天体衝突史が明らかになることで，地球へ の天体衝突史の解明にもつながることが期待される。月一 地球系への天体衝突は水や生命起源物質の運搬, 生命の誕 生・絶滅に多大な影響を与えた可能性がある。本稿では割 愛したが, 隕石中の輝石, 長石, 炭素など様々な高圧相の 研究も近年急速に進みつつある(例えば, Tomioka and Fujino, 1997; Gillet et al., 2000; Tomioka and Kimura, 2003; Sekine et al., 2006; Ferroir et al., 2010; Zhang et al., 2010; Miyahara et al., 2013b; Nakamuta and Toh, 2013)。これま でに膨大な数の隕石が回収されて抢り，まだまだ未知の鉱 物や現象が数多く残されており, 取り組むべき課題は多い。 FIB や TEM が一般化した現在, 隕石中の高圧相を取り扱 うことは以前と比べてそのハードルは低くなっている。本 稿を期に合成された高圧相だけでなく, 天然の高圧相にも 興味を持っていただければ幸いである。

謝 辞 隕石中の高圧鉱物の記載と衝撃変成過程の議論 に抢いて, 本研究奨励賞に推薦して頂いた東北大学理学研 究科の大谷栄治教授をはじめ，木村 眞教授, Ahmed El Goresy 教授, Philippe Gillet 教授, Yangting Lin 教授, 富 岡尚敬准教授, 長瀬敏郎准教授, 西嶋雅彦准教授, 三河内 岳准教授, 久保友明准教授, 荒井朋子博士, 山口 亮博 士，小澤 信博士，境 毅博士，平尾直久博士，金子詳平 氏から数多くの有益な助言と技術的支援を頂きました。こ こに紹介した研究は東北大学グローバル COE プログラム 「变動地球惑星学の統合教育研究拠点」及び「文部科学省 先端研究施設共用イノベーション創出事業: 東北大学ナノ テク融合技術支援センター」の支援を受けて行われたもの で感謝いたします。最後に, 本稿を執筆する機会を与えて 下さった日本鉣物科学会に感謝を申し上げます。

\section{引用文献}

Acosta-Maeda, T.E., Scott, E.R.D., Sharma, S.K. and Misra, A.K. (2013): The pressures and temperatures of meteorite impact: Evidence from micro-Raman mapping of mineral phases in the strongly shocked Taiban ordinary chondrite. Amer. Mineral., 98, 859-869.

Badjukov, D.D., Brandstaetter, F., Kurat, G., Libowitzky, E. and Raitala, J. (2005): Ringwoodite-olivine assemblages in Dhofar 922 L6 melt veins. Lunar and Planetary Science XXXVI, 1684. pdf.

Barrat, J.A., Chaussidon, M., Bohn, M., Gillet, Ph., GöpelL, C. and Lesourd, M. (2005): Lithium behavior during cooling of a dry basalt: An ion-microprobe study of the lunar meteorite Northwest Africa 479 (NWA 479). Geochim. Cosmochim. Acta, 69, 5597-5609.

Barrat, J.A., Gillet, Ph., Sautter, V., Jambon, A., Javoy, M., Gopel, C., Lesourd, M., Keller, F. and Petit, E. (2002): Petrology and chemistry of the basaltic shergottite North West Africa 480. Meteorit. Planet. Sci., 37, 487-499.

Baziotis, I.P., Liu, Y., DeCarli, P.S., Melosh, H.J., McSween, H.Y., Bodnar, R.J. and Taylor, L.A. (2013): The Tissint Mar- 
tian meteorite as evidence for the largest impact excavation. Nat. Commun., doi: 10.1038/ncomms2414.

Beck, P., Gillet, Ph., El Goresy, A. and Mostefaoui, S. (2005): Timescales of shock processes in chondritic and martian meteorites. Nature, 435, 1071-1074.

Binns, R.A., Davis, R.J. and Reed, S.J.B. (1969): Ringwoodite, natural $(\mathrm{Mg}, \mathrm{Fe})_{2} \mathrm{SiO}_{4}$ spinel in the Tenham meteorite. Nature, 221, 943-944.

Bläß, U.W. (2013): Shock-induced formation mechanism of seifertite in shergottites. Phys. Chem. Minerals, 40, 425-437.

Chao, E.C.T., Fahey, J.J., Littler, J. and Milton, D.J. (1962): Stishovite, $\mathrm{SiO}_{2}$, a very high pressure new mineral from Meteor Crater, Arizona. J. Geophys. Res., 67, 419-421.

Chao, E.C.T., Shoemaker, E.M. and Madsen, B.M. (1960): First natural occurrence of coesite. Science 132, 220-222.

Chen, M., Chen, J., Xie, X. and Xu, J. (2007): A microstructural investigation of natural lamellar ringwoodite in olivine of the shocked Sixiangkou chondrite. Earth Planet. Sci. Lett., 264, 277-283.

Chen, M., El Goresy, A. and Gillet, Ph. (2004): Ringwoodite lamellae in olivine: clue to olivine-ringwoodite phase transition mechanisms in shocked meteorites and subducting slabs. Proc. Nat. Acad. Sci. U.S.A., 101, 15033-15037.

Chen, M., Li, H., El Goresy, A., Liu, J. and Xie, X. (2006): Fracture-related intracrystalline transformation of olivine to ringwoodite in the shocked Sixiangkou meteorite. Meteorit. Planet. Sci., 41, 731-737.

Chen, M., Sharp, T.G., El Goresy, A., Wopenka, B. and Xie, X. (1996): The majorite-pyrope + magnesiowüstite assemblage: constrains on the history of shock veins in chondrites. Science, 271, 1570-1573.

Chen, M., Xiao, W. and Xie, X. (2010): Coesite and quartz characteristic of crystallization from shock-produced silica melt in the Xiuyan crater. Earth Planet. Sci. Lett., 297, 306-314.

El Goresy, A., Dera, P., Sharp, T.G., Prewitt, C., Chen, M., Dubrovinsky, L., Wopenka, B., Boctor, N.Z. and Hemley, R.J. (2008): Seifertite, a dense orthorhombic polymorph of silica from the Martian meteorites Shergotty and Zagami. Eur. J. Mineral., 20, 523-528.

El Goresy, A., Dubrovinsky, L., Sharp, T.G., Saxena, S.K. and Chen, M. (2000): A monoclinic post-stishovite polymorph of silica in the Shergotty meteorite. Science, 288, 1632-1634.

El Goresy, A., Gillet, Ph., Miyahara, M., Ohtani, E., Ozawa, S., Beck, P. and Montagnac, G. (2013): Shock-induced deformation of Shergottites: Shock-pressures and perturbations of magmatic ages on Mars. Geochim. Cosmochim. Acta, 101, 233262.

Feng, L., Lin, Y., Hu, S., Xu, L. and Miao, B. (2011): Estimating compositions of natural ringwoodite in the heavily shocked Grove Mountains 052049 meteorite from Raman spectra. Amer. Mineral., 96, 1480-1489.

Ferroir, T., Dubrovinsky, L., El Goresy, A., Simionovici, A., Nakamura, T. and Gillet, Ph. (2010): Carbon polymorphism in shocked meteorites: Evidence for new natural ultrahard phases. Earth. Planet. Sci. Lett., 290, 150-154.

Fritz, J. and Greshake, A. (2009): High-pressure phases in an ultramafic rock from Mars. Earth. Planet. Sci. Lett., 288, 619-623.

Gillet, Ph., Chen, M., Dubrovinsky, L. and El Goresy, A. (2000): Natural $\mathrm{NaAlSi}_{3} \mathrm{O}_{8}$-hollandite in the shocked Sixiangkou meteorite. Science, 287, 1633-1636.

Greshake, A., Fritz, J., Böttger, U. and Goran, D. (2013): Shearinduced ringwoodite formation in the Martian shergottite Dar
alGani 670. Earth Planet. Sci. Lett., 375, 383-394.

Kerschhofer, L., Dupas, C., Liu, M., Sharp, T.G., Durham, W.B. and Rubie, D.C. (1998): Polymorphic transformations between olivine, wadsleyite and ringwoodite: mechanisms of intracrystalline nucleation and the role of elastic strain. Mineral. Mag., 62, 617-638.

Kerschhofer, L., Rubie, D.C., Sharp, T.G., McConnell, J.D.C. and Dupas-Bruzek, C. (2000): Kinetics of intracrystalline olivineringwoodite transformation. Phys. Earth Planet. Inter., 121, 59-76.

Kerschhofer, L., Sharp, T.G. and Rubie, D.C. (1996): Intracrystalline transformation of olivine to wadsleyite and ringwoodite under subduction zone conditions. Science, 274, 79-81.

Kimura, M., Suzuki, A., Kondo, T., Ohtani, E. and El Goresy, A. (2000): Natural occurrence of high-pressure phases jadeite, hollandite, wadsleyite, and majorite-pyrope garnet in an $\mathrm{H}$ chondrite, Yamato 75100. Meteorit. Planet. Sci., 35, A87-A88.

Kubo, T., Ohtani, E., Kato, T., Urakawa, S., Suzuki, A., Kanbe, Y., Funakoshi, K., Utsumi, W., Kikegawa, T. and Fujino K. (2002): Mechanisms and kinetics of the post-spinel transformation in $\mathrm{Mg}_{2} \mathrm{SiO}_{4}$. Phys. Earth Planet. Inter., 129, 153-171.

Kuwayama, Y., Hirose, K., Sata, N. and Ohishi. Y. (2005): The pyrite-type high-pressure form of silica. Science, 309, 923-925.

Lakshtanov, D.L., Sinogeikin, S.V., Litasov, K.D., Prakapenka, V.B., Hellwig, H., Wang, J., Sanches-Valle, C., Perrillat, J.P., Chen, B., Somayazulu, M., Li, J., Ohtani, E. and Bass, J.D. (2007): The post-stishovite phase transition in hydrous alumina-bearing $\mathrm{SiO}_{2}$ in the lower mantle of the earth. Proc. Nat. Acad. Sci. U.S.A., 104, 13588-13590.

Miyahara, M., El Goresy, A., Ohtani, E., Kimura, M., Ozawa, S., Nagase, T. and Nishijima, M. (2009): Fractional crystallization of olivine melt inclusion in shock-induced chondritic melt vein. Phys. Earth Planet. Inter., 177, 116-121.

Miyahara, M., El Goresy, A., Ohtani, E., Nagase, T., Nishijima, M., Vashaei, Z., Ferroir, T., Gillet, Ph., Dubrovinsky, L. and Simionovici, A. (2008): Evidence for fractional crystallization of wadsleyite and ringwoodite from olivine melts in chondrules entrained in shock-melt veins. Proc. Nat. Acad. Sci. U.S.A., 105, 8542-8547.

Miyahara, M., Kaneko, S., Ohtani, E., Sakai, T., Nagase, T., Kayama, M., Nishido, H. and Hirao, N. (2013a): Discovery of seifertite in a shocked lunar meteorite. Nat. Commun., doi: $10.1038 /$ ncomms 2733 .

Miyahara, M., Ohtani, E., Kimura, M., El Goresy, A., Ozawa, S., Nagase, T., Nishijima, M. and Hiraga, K. (2010): Coherent and subsequent incoherent ringwoodite growth in olivine of shocked L6 chondrites. Earth Planet. Sci. Lett., 295, 321-327.

Miyahara, M., Ohtani, E., Ozawa, S., Kimura, M., El Goresy, A., Sakai, T., Nagase, T., Hiraga, K., Hirao, N. and Ohishi, Y. (2011): Natural dissociation of olivine to $(\mathrm{Mg}, \mathrm{Fe}) \mathrm{SiO}_{3}$ perovskite and magnesiowüstite in a shocked Martian meteorite. Proc. Nat. Acad. Sci. U.S.A., 108, 5999-6003.

Miyahara, M., Ozawa, S., Ohtani, E., Kimura, M., Kubo, T., Sakai, T., Nagase, T., Nishijima, M. and Hirao, N. (2013b): Jadeite formation in shocked ordinary chondrites. Earth Planet. Sci. Lett., 373, 102-108.

Nakamura, E., Makishima, A., Moriguti, T., Kobayashi, K., Tanaka, R., Kunihiro, T., Tsujimori, T., Sakaguchi, C., Kitagawa, H., Ota, T., Yachi, Y., Yada, T., Abe, M., Fujimura, A., Ueno, M., Mukai, T., Yoshikawa, M. and Kawaguchi, J. (2012): Space environment of an asteroid preserved on micrograins returned by the Hayabusa spacecraft. Proc. Nat. 
Acad. Sci. U.S.A., 109, E624-E629.

Nakamura, T, Noguchi, T., Tanaka, M., Zolensky, M.E., Kimura, M., Tsuchiyama, A., Nakato, A., Ogami, T., Ishida, H., Uesugi, M., Yada, T., Shirai, K., Fujimura, A., Okazaki, R., Sandford, S.A., Ishibashi, Y., Abe, M., Okada, T., Ueno, M., Mukai, T., Yoshikawa, M. and Kawaguchi, J. (2011): Itokawa dust particles: A direct link between S-type asteroids and ordinary chondrites. Science, 333, 1113-1116.

Nakamuta, Y. and Toh, S. (2013): Transformation of graphite to lonsdaleite and diamond in the Goalpara ureilite directly observed by TEM. Amer. Mineral., 98, 574-581.

Ohtani, E., Kimura, Y., Kimura, M., Takata, T., Kondo, T. and Kubo, T. (2004): Formation of high-pressure minerals in shocked L6 chondrite Yamato 791384: constraints on shock conditions and parent body size. Earth Planet. Sci. Lett., 227, 505-515.

Ohtani, E., Ozawa, S., Miyahara, M., Ito, Y., Mikouchi, T., Kimura, M., Arai, T., Sato, K. and Hiraga, K. (2011): Coesite and Stishovite in a shocked lunar meteorite, Asuka-881757, and impact events in lunar surface. Proc. Nat. Acad. Sci. U.S.A., 108, 463-466.

Ozawa, S., Ohtani, E., Miyahara, M., Suzuki, A., Kimura, M. and Ito, Y. (2009): Transformation textures, mechanisms of formation of high-pressure minerals in shock melt veins of L6 chondrites, and pressure-temperature conditions of the shock events. Meteorit. Planet. Sci., 44, 1771-1786.

Presnall, D.C. (1995): Phase diagrams of Earth-Forming Minerals., In Mineral Physics \& Crystallography, A Handbook of Physical Costants (Ahrens, T.J. Ed.). AGU, Washington D.C., 248-268.

Price, G.D., Putnis, A., Agrell, S.O. and Smith, D.G.W. (1983): Wadsleyite, natural beta $-(\mathrm{Mg}, \mathrm{Fe})_{2} \mathrm{SiO}_{4}$ from the Peace River Meteorite, Can. Mineral., 21, 29-53.

Sakai, T., Ohtani, E., Terasaki, H., Sawada, N., Kobayashi, Y., Miyahara, M., Nishijima, M., Hirao, N., Ohishi, Y. and Kikegawa, T. (2009): $\mathrm{Fe}-\mathrm{Mg}$ partitioning between perovskite and ferropericlase at the lower mantle. Amer. Mineral., 94, 921-925.

Sekine, T., He, H., Kobayashi, T. and Shibata, K. (2006): Sinoite $\left(\mathrm{Si}_{2} \mathrm{~N}_{2} \mathrm{O}\right)$ shocked at pressures of 28 to $64 \mathrm{GPa}$. Amer. Mineral., 91, 463-466.

Stähle, V., Altherr, R., Koch, M. and Nasdala, L. (2008): Shockinduced growth and metastability of stishovite and coesite in lithic clasts from suevite of the Rise impact crater (Germany). Contrib. Mineral. Petrol., 155, 457-472.

Stöffler, D., Ostertag, R., Jammes, C., Pfannschmidt, G., Sen Gup- ta, P.R., Simon, S.B., Papike, J.J. and Beauchamp, R.H. (1986): Shock metamorphism and petrography of the Shergotty achondrite. Geochim. Cosmochim. Acta, 50, 889-903.

Sharp, T.G., El Goresy, A., Wopenka, B. and Chen, M. (1999): A post-stishovite $\mathrm{SiO}_{2}$ polymorph in the meteorite Shergotty: Implications for impact events. Science, 284, 1511-513.

Smyth, J.R. and Hatton, C.J. (1977): A coesite-sanidine grospydite from the Roberts victor kimberlite. Earth Planet. Sci. Lett., 34, 284-290.

Tomioka, N. and Fujino, K. (1997): Natural (Mg, Fe) $\mathrm{SiO}_{3}-$ ilmenite and -perovskite in the Tenham Meteorite. Science 277, 1084-1086.

Tomioka, N. and Kimura, M. (2003): The breakdown of diopside to $\mathrm{Ca}$-rich majorite and glass in a shocked $\mathrm{H}$ chondrite. Earth Planet. Sci. Lett., 208, 271-278.

Tschauner, O., Asimow, P.D., Kostandova, N., Ahrens, T.J., Ma, C., Sinogeikin, S., Liu, Z., Fakra, S. and Tamura, N. (2009): Ultrafast growth of wadsleyite in shock-produced melts and its implications for early solar system impact processes. Proc. Nat. Acad. Sci. U.S.A., 106, 13691-13695.

Tsuchida, Y. and Yagi, T. (1989): A new, post-stishovite highpressure polymorph of silica. Nature, 340, 217-220.

Weisberg, M.K. and Kimura, M. (2010): Petrology and Raman spectroscopy of high pressure phases in the Gujba CB chondrite and the shock history of the CB parent body. Meteorit. Planet. Sci., 45, 873-884.

Walton, E.L. (2013): Shock metamorphism of Elephant Moraine A79001: Implications for olivine-ringwoodite transformation and the complex thermal history of heavily shocked Martian meteorites. Geochim. Cosmochim. Acta, 107, 299-315.

Xie, Z., Li, X., Sharp, T.G. and De Carli, P.S. (2010): Ringwoodite rims around olivine cores in shock-induced melt veins of an Antarctic chondrite: Mechanisms of transformation and $\mathrm{Fe}^{-}$ Mg diffusion. Meteorit. Planet. Sci., 45, A219.

Xie, Z. and Sharp, T.G. (2007): Host rock solid-state transformation in a shock-induced melt vein of Tenham L6 chondrite. Earth Planet. Sci. Lett., 254, 433-445.

Xie, Z., Sharp, T.G. and DeCarli, P.S. (2006): High-pressure phases in a shock-induced melt vein of the Tenham L6 chondrite: Constraints on shock pressure and duration. Geochim. Cosmochim. Acta, 70, 504-515.

Zhang, A.-C., Hsu, W.-B., Li, X.-H., Ming, H.-L., Li, Q.-L., Liu, Y. and Tang, G.-Q. (2010): Impact melting of lunar meteorite Dhofar 458: Evidence from polycrystalline texture and decomposition of zircon. Meteorit. Planet. Sci., 46, 103-115. 